\title{
Assessment of lodine Deficiency among School-Going Children of Age Group 6 to 12 Years in Kachchh District, Gujarat State: Cross-Sectional Hospital-Based Study
}

\author{
Dinesh P. Sharma ${ }^{1, \odot} \quad$ Amitkumar Maheshwari ${ }^{1} \quad$ Chandan Chakrabarti ${ }^{2}$ Darshan J. Patel ${ }^{1}$ \\ ${ }^{1}$ Department of Biochemistry, Gujarat Adani Institute of Medical \\ Address for correspondence Dinesh P. Sharma, PhD, Department \\ Sciences, Bhuj, Gujarat, India \\ 2Department of Biochemistry, Smt. NHL Municipal Medical College, \\ of Biochemistry, Gujarat Adani Institute of Medical Sciences, \\ Bhuj 370001,Gujarat, India (e-mail: dksharma0305@gmail.com).
} Ahmedabad, Gujarat University, Gujarat, India

\begin{abstract}
Keywords

- iodine deficiency disorders (IDD)

- school children

- prevalence of goitre

- iodized salts

- urine iodine excretion

Aim lodine deficiency disorder (IDD) is the cause of preventable brain damage, mental retardation, and stunted growth and development in children. This study aimed to detect the prevalence of IDD in Kachchh district, Gujarat, by testing urinary iodine excretion levels and iodine intake of salts in school-going children.

Methods A cross-sectional study was conducted and the level of iodine deficiency was assessed in 223 school children of both sexes, aged 6 to 12 years from four talukas, that is, subdivisions, of the Kachchh district by estimating urinary iodine using Sandell-Kolthoff reaction along with iodine content in edible salt samples by MBI kit (STK-Spot testing kit, MBI Kits International, Chennai, TN, India).

Results The median urinary iodine level was found to be $194 \mu \mathrm{g} / \mathrm{L}$, indicating no biochemical iodine deficiency in the region. In the study areas, $1 \%$ of the population showed a level of urinary iodine excretion $<50 \mu \mathrm{g} / \mathrm{L}$. About $83 \%$ salt samples had iodine level more than $15 \mathrm{ppm}$ and the iodine content in salt samples less than $15 \mathrm{ppm}$ was only about $17 \%$, indicating the salt samples at households contain iodine in adequate level.

Conclusion There is a need of periodic surveys to assess the change in magnitude of IDD with respect to impact of iodized salt intervention.

Furthermore, to strengthen National lodine Deficiency Disorders Control Program, factors should be identified. There is also a need to prevent and reimpose the ban on the sale of noniodized salts in Gujarat.
\end{abstract}

\section{Introduction}

Iodine is an essential micronutrient for normal human growth and mental development with an average requirement

published online July 6, 2021
DOI https://doi.org/

$10.1055 / \mathrm{s}-0041-1731138$ ISSN 0974-2727 of 100 to $150 \mu \mathrm{g} /$ day. Inadequate or poor intake of iodine affects people of all ages of both sexes and of different socioeconomic backgrounds. The disorders caused due to deficiency of nutritional iodine in the food or diet are called
(C) 2021 . The Indian Association of Laboratory Physicians.
This is an open access article published by Thieme under the terms of the Creative
Commons Attribution-NonDerivative-NonCommercial-License, permitting copying
and reproduction so long as the original work is given appropriate credit. Contents
may not be used for commercial purposes, or adapted, remixed, transformed or
built upon. (https://creativecommons.org/licenses/by-nc-nd/4.0/).
Thieme Medical and Scientific Publishers Pvt. Ltd. A-12, 2nd Floor,
Sector 2, Noida-201301 UP, India 
iodine deficiency disorders (IDDs)., ${ }^{1,2}$ Urinary iodine is a well-accepted, cost-efficient, and easily obtainable indicator for iodine status. Since the majority of iodine absorbed by the body is excreted in the urine, ${ }^{3,4}$ it is considered as a sensitive marker of current iodine intake and would reflect recent changes in iodine status. ${ }^{4.5}$ IDD is a significant public health problem and is the most common cause of brain damage throughout the world (World Health Organization [WHO]/ United Nations Children's Fund [UNICEF]/International Council for Control of Iodine Deficiency Disorder [ICCIDD], 1992). Due to glaciations, flooding, rivers changing course, and deforestation, iodine present in topsoil is constantly leached, leading iodine deficiency in the soil. This, in turn, causes deficiency of iodine in crops grown on iodine-deficient soil, which results in low iodine in the diet for livestock and humans. In the past it was thought that only goitre and cretinism were caused by iodine deficiency. However, over the past, it has become increasingly clear that iodine deficiency leads to a much wider spectrum of disorders including goitre, cretinism, hypothyroidism, brain damage, abortion, still birth, mental retardation, psychomotor defects, and hearing and speech impairment. ${ }^{6}$ In an attempt to eliminate iodine deficiency and act in accordance with the international goal of universal salt iodization, mandatory iodization of all table salts was introduced in India in 1983. In June 1992, the National Goitre Control Program (NGCP) was appropriately redesigned as "National Iodine Deficiency Disorders Control Programme (NIDDCP)" in recognition of the spectrum of disorders due to deficiency of iodine. The goal of NIDDCP was to lessen the prevalence of iodine deficiency disorders to below $10 \%$ in endemic districts of the country by the year $2000 .{ }^{7}$ Since January 2001, the government of Gujarat state withdrew the notification of banning sale of noniodized salt. Afterwards, in November 2005, thecentral government issued a notification to ban the sale of noniodized salts for direct human consumption in the entire country, which was effective from May 17, 2006, under the Food Adulteration Act. From January 2001 to June 2006, there was no ban on the sale of noniodized salts. ${ }^{8}$ In Kachchh district, IDD survey was done in 1990-1991, and then re-survey was done in 1999-2000 and in 2009 to document the prevalence of goitre in primary school children of the age group 6 to 12 years, determine median urinary iodine concentration in sample of children, assess the level of iodine in salt samples at retail trader level, and study the profile of salt sold at retail shops. ${ }^{9}$ To know the current status of iodine nutrition, the present study was conducted to detect the prevalence of iodine deficiency disorder by knowing the pattern of urinary iodine excretion in primary school-going children, and level of iodine content in edible salt, in the Kachchh district.

\section{Materials and Methods}

\section{Selection of Study Area and Population}

The present study was done in Kachchh district of Gujarat state. The main source of water is rain and all type of routine vegetables are available and consumed by the people. The district has a total populations of $1,583,225$, as per the 2001 census. ${ }^{10}$ The national program was implemented in the district in 1992 after the result of baseline survey conducted in 1990, which indicated low goitre prevalence. As per the recommendation of WHO/UNICEF/ICCIDD, ${ }^{11}$ a cross-sectional study of school children in the age group 6 to 12 years was done and children from both sexes were selected. The study included school survey and community survey. Five boys and five girls from each grade were selected randomly in a class on the day of visit for examination.

\section{Sampling Method}

The villages were selected using cluster sampling method. ${ }^{12} \mathrm{~A}$ list of villages of all talukas of Kachchh district was obtained from the zila panchayat office of the district health office (DHO).Then cumulative population was counted by using MS Excel. By calculating cluster interval, four villages were selected from the list. Only rural areas were included and confined and urban population was excluded in calculating cumulative population. When the desired sample size of five boys and five girls from each grade was not achieved, a primary school of the nearest village was approached and similarly, community survey was also done.

\section{Training and Survey Technique}

School children were clinically examined for the enlargement of thyroid (goitre) by palpation method endorsed by the current survey included in the WHO grading system as per the revised guidelines under $\mathrm{NIDDCP}^{13}$ and WHO/UNICEF/ICCIDD. The child was examined by the examiner in sitting position, with neck in normal position. The following classification was used for goiter-grade 0 : no goiter, grade 1 : thyroid palpable but not visible, and grade 2: thyroid visible with the neck in normal position. ${ }^{14}$

\section{lodine in Urine}

Five boys and five girls from first to seventh grade were selected randomly for urine sampling. In each cluster, 25 urine samples were collected, including 5 samples from boys and 5 from girls on the spot, according to the revised national guidelines for estimation of urinary iodine excretion (UIE). ${ }^{12-15}$ In 30 clusters, total 223 urine samples were collected and tested for urinary iodine excretion. To collect urine samples, plastic bottles with screw caps were used and added with few drops of toluene to inhibit bacterial growth and to minimize bad odor. Ammonium persulfate titration method was used to detect the urinary iodine excretion level. The method is based on the principle that urinary iodine is released after the ingestion of urine with ammonium persulfate. The released iodine catalyzes the reduction of ceric ammonium sulfate (yellow) to cerous form (colorless) (Sandell-Kolthoff reaction). ${ }^{16}$ Color disappearance was measured by a spectrophotometer in form of optical density (OD), which was subsequently measured by constructing a standard curve on graph paper by plotting iodine concentration 
in $\mu \mathrm{g} / \mathrm{L}$. Median iodine concentration of $>100 \mu \mathrm{g} / \mathrm{L}$ defines a population with no iodine deficiency, that is, at least $50 \%$ of the samples should be above $100 \mu \mathrm{g} / \mathrm{L}$ according to the epidemiological criteria. ${ }^{17}$ In adults, under steady state conditions, a urinary iodine concentration of $100 \mu \mathrm{g} / \mathrm{L}$ corresponds roughly to a daily intake of about $150 \mu \mathrm{g} / \mathrm{L}$.

\section{lodine in Salt}

As per the protocol during the school survey to monitor iodine content in salt samples, marked air-tight plastic containers were distributed ${ }^{18}$ randomly to the students and they were asked to bring edible salt samples from their households. Samples were also collected from the houses of students from each cluster. These samples were tested qualitatively on the spot with MBI kit provided by UNICEF, and iodine concentration was recorded as $0,<15$, or $>15 \mathrm{ppm} .{ }^{19}$ One retail shop in each village was also visited and samples were purchased and tested with the use of spot salt testing kit for the presence of iodine.

\section{Data Analysis}

All the data were entered in MS Excel 2007 and analyzed using the Epi Info software, version 3.5.1 (Centers for Disease Control and Prevention, Atlanta, Georgia). ${ }^{20}$

\section{Observation and Results}

Total 223 urine samples were examined and obtained data were analyzed with the help of WHO/UNICEF/ICCIDD guidelines $^{21}$ as given in - Table 1 .

Table 1 Epidemiological criteria based on the World Health Organization/United Nations Children's Fund/International Council for Control of Iodine Deficiency Disorder guidelines

\begin{tabular}{|l|l|l|}
\hline $\begin{array}{l}\text { Urine iodine } \\
\text { in children } \\
(\mu \mathrm{g} / \mathrm{L})\end{array}$ & $\begin{array}{l}\text { lodine } \\
\text { intake }\end{array}$ & lodine status \\
\hline$<20$ & Insufficient & Severe deficiency \\
\hline $20-49$ & Insufficient & Moderate deficiency \\
\hline $50-99$ & Insufficient & Mild deficiency \\
\hline $100-199$ & Adequate & Optimal \\
\hline $200-299$ & $\begin{array}{l}\text { More than } \\
\text { adequate }\end{array}$ & $\begin{array}{l}\text { Risk of iodine-induced } \\
\text { hyperthyroidism }\end{array}$ \\
\hline$\geq 300$ & Excessive & $\begin{array}{l}\text { Risk of hyperthyroidism and } \\
\text { autoimmune thyroid disease }\end{array}$ \\
\hline
\end{tabular}

\section{Results}

The present cross-sectional study assessed the iodine status of 6- to 12-year-old school-going children $(N=223)$, by estimating urinary iodine using Sandell-Kolthoff reaction. Out of the 223 urine samples collected, 99\% samples were found with urinary iodine excretion (UIE) level $100 \mu \mathrm{g} / \mathrm{L}$ or more, while $1 \%$ showed less than $100 \mu \mathrm{g} / \mathrm{L}$ (depicted in - Table 2 ). The median urinary iodine level was found to be $194 \mu \mathrm{g} / \mathrm{L}$, indicating no biochemical iodine deficiency in the region (depicted in - Table 3). In the study areas, $1 \%$ of the population showed a level of urinary iodine excretion $<50 \mu \mathrm{g} / \mathrm{L}$ (depicted in - Table 4). About $83 \%$ salt samples had iodine level more than $15 \mathrm{ppm}$ and the iodine content in salt samples less than 15 ppm was only about $17 \%$, indicating the salt samples at households contain iodine in adequate level (depicted in - Table 5) but fall below criteria for monitoring progress toward eliminating IDD as a public health problem.

Table 2 Distribution of urinary iodine $(n=223)$

\begin{tabular}{|l|l|l|}
\hline Urinary lodine $(\mu \mathrm{g} / \mathrm{L})$ & $\begin{array}{l}n \\
(223)\end{array}$ & $\%$ (percentage) \\
\hline$<100$ & 2 & 1 \\
\hline $100-200$ & 108 & 48 \\
\hline $200-490$ & 102 & 46 \\
\hline $500-990$ & 11 & 5 \\
\hline$<1,000$ & 0 & 100 \\
\hline$\geq 1,000$ & 0 & 0 \\
\hline
\end{tabular}

Note: Out of the 223 urine samples collected, $99 \%$ samples were found with urinary iodine excretion (UIE) level $100 \mu \mathrm{g} / \mathrm{L}$ or more, while $1 \%$ showed less than $100 \mu \mathrm{g} / \mathrm{L}$.

Table 3 Median urinary iodine excretion (UIE) level in Kachchh district $(\mu \mathrm{g} / \mathrm{L})$

\begin{tabular}{|l|l|}
\hline Taluka & $\begin{array}{l}\text { Median UIC } \\
(\mu \mathrm{g} / \mathrm{L})\end{array}$ \\
\hline Bhuj & 185 \\
\hline Nakhatrana & 192 \\
\hline Khothara & 196 \\
\hline Anjar & 225 \\
\hline Median & 194 \\
\hline
\end{tabular}

Note: The median urinary iodine level was $194 \mu \mathrm{g} / \mathrm{L}$, indicating no biochemical iodine deficiency in the region.

Table 4 Urinary iodine excretion (UIE) level in rural areas of Kachchh district

\begin{tabular}{|l|l|l|l|}
\hline \multirow{2}{*}{ Taluka } & \multirow{2}{*}{$n$} & \multicolumn{2}{|c|}{ Urinary iodine excretion (UIE) } \\
\cline { 3 - 4 } & & $<50 \mu \mathrm{g} / \mathrm{L} \mathrm{( \% )}$ & $>50 \mu \mathrm{g} / \mathrm{L}(\%)$ \\
\hline Anjar & 50 & $1(2)$ & $49(98)$ \\
\hline Nakhatrana & 50 & 0 & $50(100)$ \\
\hline Kothara & 53 & 0 & $53(100)$ \\
\hline Bhuj & 70 & 0 & $70(100)$ \\
\hline Total & 223 & 1 & $222(99)$ \\
\hline
\end{tabular}

Note: $1 \%$ showed urinary iodine excretion (UIE) level $<50 \mu \mathrm{g} / \mathrm{L}$, while $99 \%$ showed a level $\geq 50 \mu \mathrm{g} / \mathrm{L}$. 
Table 5 Salt lodization level in rural areas of Kachchh district

\begin{tabular}{|l|l|l|l|l|l|}
\hline \multirow{2}{*}{ Taluka } & $\begin{array}{l}\text { No. of salt samples } \\
\text { tested }\end{array}$ & \multicolumn{4}{|c|}{ lodization of salt (ppm) (MBI kit) } \\
\cline { 3 - 6 } & & $0 \mathrm{ppm}$ & $<15 \mathrm{ppm}$ & $>15 \mathrm{ppm}$ & $\begin{array}{l}\text { Percentage (\%) of salt samples } \\
\text { adequately iodized }\end{array}$ \\
\hline Anjar & 50 & 0 & 8 & 42 & 84 \\
\hline Nakhatrana & 50 & 0 & 8 & 42 & 84 \\
\hline Kothara & 53 & 0 & 12 & 41 & 77 \\
\hline Bhuj & 70 & 0 & 10 & 60 & 86 \\
\hline & Total & & $17 \%$ & $82 \%$ & \\
\hline
\end{tabular}

Note: The iodine content of 223 salt samples was assessed by the MBI kit method provided by UNICEF, out of which $82 \%$ salt samples showed adequate iodine (> $15 \mathrm{ppm})$ and $17 \%$ showed $<15 \mathrm{ppm}$ iodine.

Table 6 Goitre prevalence rate in various talukas of Kachchh district

\begin{tabular}{|c|c|c|c|c|c|c|}
\hline Taluka & Grade 0 & Grade 1 & Grade 2 & Total cases & $\begin{array}{l}\text { Total children } \\
\text { examined }\end{array}$ & Prevalence rate (\%) \\
\hline Anjar & 0 & 1 & 0 & 1 & 50 & 2 \\
\hline Nakhatrana & 0 & 1 & 1 & 2 & 50 & 4 \\
\hline Kothara & 0 & 1 & 0 & 1 & 53 & 1.88 \\
\hline Bhuj & 0 & 1 & 0 & 1 & 70 & 1.42 \\
\hline
\end{tabular}

\section{Discussion}

The most widely accepted marker for the evaluation for severity of IDD is the prevalence of endemic goitre in school-going children. WHO/UNICEF/ICCIDD ${ }^{22}$ and on the basis of IDD prevalence, the criteria to understand the severity of IDD as a public health problem. As per this criteria, the prevalence rate for mild deficiency is 5.0 to $19.9 \%, 20$ to $29.9 \%$ is moderate, and $30 \%$ and above is considered as severe. In the present study, the median urinary iodine level is $194 \mu \mathrm{g} / \mathrm{L}$, indicating no biochemical iodine deficiency in the region. A study done from another district of Gujarat showed prevalence of goitre to be $20.5 \%,{ }^{23}$ which was very high compared with the present study (depicted in - Table 6). Since January 2001, the ban on the sale of noniodized salts in Gujarat was withdrawn, and in November 2005 the central government issued notification to ban the sale of noniodized salts for direct consumption in the entire country. ${ }^{8}$ Chandra et $\mathrm{al}^{24}$ reported more than $95 \%$ of population consuming salts at adequate level, while Kamath et $\mathrm{al}^{25}$ and Biswas et $\mathrm{al}^{26}$ reported only $50 \%$ of community consuming salts at

Table 7 Criteria for monitoring progress toward eliminating iodine deficiency disorder (IDD) as a public health problem ${ }^{14}$

\begin{tabular}{|l|l|}
\hline Indicator & Goal \\
\hline Urinary iodine* & \\
\hline Proportion below $100 \mu \mathrm{g} / \mathrm{L}$ & $<50 \%$ \\
\hline Proportion below $50 \mu \mathrm{g} / \mathrm{L}$ & $<20 \%$ \\
\hline Salt iodization & \\
\hline $\begin{array}{l}\text { Proportion of households consuming effectively } \\
\text { iodized salts }\end{array}$ & $>90 \%$ \\
\hline
\end{tabular}

adequate level. Mishra et $\mathrm{al}^{23}$ reported 39\% with less than $30 \mathrm{ppm}$ iodine level at retail shops, which indicates higher availability of iodine in iodized salts in the present study. As per WHO/UNICEF/ICCIDD, proportion of households consuming iodized salts effectively should be more than $90 \%$ and the recommended level of iodized salts should be more than $15 \mathrm{ppm}^{27}$ (depicted in - Table 7); the present study shows $83 \%$ salt samples had more than 15 ppm iodine present. Hence the present study indicates the need to continue adequate effort of supplying iodized salts to the region and strengthen the system of monitoring.

\section{Conclusion}

The results of the present study indicate that the lowest urinary iodine excretion was seen in the age group of 11 years, whereas highest urinary iodine excretion was seen in the age group of 6 to 10 years (depicted in - Table 8 ).

There is a need of periodic surveys to assess the change in magnitude of the IDD with respect to the impact of iodized salt intervention. Furthermore, this calls for the identification of factors to strengthen NIDDCP and the need to reimpose the ban on the sale of noniodized salts in Gujarat.

\section{Ethics Approval}

This study was approved by the Institutional Ethical Committee of Gujarat Adani Institute of Medical Sciences, Bhuj, and the authors received no funding for this study.

\section{Consent to Participate}

Written informed consent were obtained from parents.

\section{Conflict of Interest}

None declared. 
Table 8 Age-wise analysis of urinary iodine excretion

\begin{tabular}{|c|c|c|c|c|c|c|c|c|c|c|c|}
\hline \multicolumn{12}{|c|}{$[\mathrm{A}]$} \\
\hline \multicolumn{12}{|c|}{ Age-wise distribution of urinary iodine $(n=223)$} \\
\hline \multirow[t]{2}{*}{ Age $(y)$} & \multirow[t]{2}{*}{$n$} & \multicolumn{2}{|c|}{$<200 \mu \mathrm{g} / \mathrm{L}$} & \multicolumn{2}{|c|}{$200-490 \mu \mathrm{g} / \mathrm{L}$} & \multicolumn{2}{|c|}{$500-990 \mu \mathrm{g} / \mathrm{L}$} & \multicolumn{2}{|c|}{$<1,000 \mu \mathrm{g} / \mathrm{L}$} & \multicolumn{2}{|c|}{$>1,000 \mu \mathrm{g} / \mathrm{L}$} \\
\hline & & $n$ & $\%$ & $n$ & $\%$ & $n$ & $\%$ & $n$ & $\%$ & $n$ & $\%$ \\
\hline 6 & 10 & 6 & 60 & 3 & 30 & 1 & 10 & 10 & 100 & 0 & 0 \\
\hline 7 & 27 & 14 & 52 & 12 & 44 & 1 & 4 & 27 & 100 & 0 & 0 \\
\hline 8 & 19 & 11 & 58 & 7 & 37 & 1 & 5 & 19 & 100 & 0 & 0 \\
\hline 9 & 34 & 14 & 41 & 19 & 56 & 1 & 3 & 34 & 100 & 0 & 0 \\
\hline 10 & 32 & 14 & 44 & 16 & 50 & 2 & 6 & 32 & 100 & 0 & 0 \\
\hline 11 & 53 & 26 & 49 & 25 & 47 & 2 & 4 & 53 & 100 & 0 & 0 \\
\hline 12 & 48 & 25 & 52 & 20 & 42 & 3 & 6 & 48 & 100 & 0 & 0 \\
\hline \multicolumn{12}{|c|}{ [B] } \\
\hline \multirow{2}{*}{\multicolumn{2}{|c|}{$\begin{array}{c}\text { Age } \\
\text { (y) }\end{array}$}} & \multicolumn{10}{|c|}{ Urinary iodine excretion } \\
\hline & & \multicolumn{3}{|c|}{$>100 \mu \mathrm{g} / \mathrm{L}(\%)$} & \multicolumn{3}{|c|}{$<100 \mu \mathrm{g} / \mathrm{L}(\%)$} & & \multicolumn{3}{|l|}{ Total } \\
\hline \multicolumn{2}{|c|}{6} & \multicolumn{3}{|c|}{$10(100)$} & \multicolumn{3}{|c|}{0} & & \multicolumn{3}{|l|}{10} \\
\hline \multicolumn{2}{|c|}{7} & \multicolumn{3}{|c|}{$27(100)$} & \multicolumn{3}{|c|}{0} & & \multicolumn{3}{|l|}{27} \\
\hline \multicolumn{2}{|c|}{8} & \multicolumn{3}{|c|}{$19(100)$} & \multicolumn{3}{|c|}{0} & & \multicolumn{3}{|l|}{19} \\
\hline \multicolumn{2}{|c|}{9} & \multicolumn{3}{|c|}{$34(100)$} & \multicolumn{3}{|c|}{0} & & \multicolumn{3}{|l|}{34} \\
\hline \multicolumn{2}{|c|}{10} & & $32(100)$ & & 0 & & & & 32 & & \\
\hline & & & $52(98.11)$ & & & 1.92) & & & 53 & & \\
\hline & & & $47(97.91)$ & & & 2.0) & & & 48 & & \\
\hline & & & 221 (99.10) & & & 0.89) & & & 223 & & \\
\hline
\end{tabular}

\section{References}

1 National Rural Health Mission IDD and Nutrition Cell. Revised Policy Guidelines on National Iodine Deficiency Disorders Control Programme. Revised ed. New Delhi, India: Directorate General of Health Services, Ministry of Health and Family Welfare, Government of India; October 2006

2 Damor J, Padhiyar N, Ninama G. Urinary iodine excretion in urine samples among children in Dahod district, Gujarat. Indian Journal of Clinical Practice 2013;23(9)

3 Gibson R, ed. Principles of Nutritional Assessment. Oxford, United Kingdom: Oxford University Press; 2005

4 World Health Organization, Urinary Iodine Concentrations for Determining Iodine Status Deficiency in Populations. Vitamin and Mineral Nutrition Information System. Geneva, Switzerland: World Health Organization; 2013

5 DeMaeyer EM, Lowenstein FW, Thilly CW, The Control of Endemic Goitre. Geneva, Switzerland: World Health Organization; 1979

6 International Council for the Control of Iodine Deficiency Disorders, In:Hetzel BS, Delange F, Dunn JT, Ling J, Mannar V, Pandav C, eds. Towards the Global Elimination of Brain Damage Due to Iodine Deficiency. New Delhi, India: Oxford University Press; 2004

7 Mohapatra SS, Bulliyya G, Kerketta AS, Acharya AS. Thyroxine and thyrotropin profile in neonates and school children in an iodine deficiency disorders endemic area of Orissa. Indian J Nutr Diet 2001;38:98-101

8 Kishore J, National Health Programmes of India, 7th ed. New Delhi, India: Century Publications,; 2007 370-373

9 Chudasama R, Patel UV, R R, Verma PH. Iodine deficiency disorders in 6-12 years old rural primary school children in Kutch district, Gujarat. Indian Pediatr 2011;48(6):453-456

102001 Census. Kutch, Gujarat, India: Office of District Health Officer; 2008
11 Dunn JT, Crutchfield HE, Gutckunst R, Dunn AD, Iodine deficiency disorders and urinary iodine levels. In: Methods of Measuring Iodine in Urine. The Netherlands: International Council for Control of Iodine Deficiency Disorder/United Nations Children's Fund/World Health Organization; 1993 7-10

12 Ministry of Health and Family Welfare, Government of India. Revised policy guidelines on National Iodine Deficiency Disorders Control Programme, 2006. available at: www.mohfw. nic.in/Revised\%20Policy\%20Guidelines\%200n\%20NIDDCP.html. Accessed September 14, 2020

13 Directorate General of Health Services (DGHS). Revised policy guidelines on National Iodine Deficiency Disorders Control Programme. New Delhi, India: DGHS, Ministry of Health and Family Welfare, Government of India; 2006:1-31. www. mohfw.nic.in/nrhm/document/revised_guidelines.pdf. Accessed September 14, 2020

14 World Health Organization; United Nations Children's Fund; International Council for Control of Iodine Deficiency Disorder. Indicators for Assessing Iodine Deficiency Disorders and Their Control Through Salt Iodization. Geneva, Switzerland: World Health Organization; 1994

15 Chudasama RK, Verma PB, Mahajan RG. Iodine nutritional status and goiter prevalence in 6-12 years primary school children of Saurashtra region, India. World J Pediatr 2010;6(3):233-237

16 World Health Organization; International Council for Control of Iodine Deficiency Disorder; United Nations Children's Fund. Assessment of Iodine Deficiency Disorders and Monitoring Their Elimination: A Guide for Programme Managers. Geneva, Switzerland: World Health Organization; 2007. Available at: www.iccidd.org/media/assessment\%20tools/urinary_iodinemethod_a.pdf.

17 World Health Organization, United Nations Children's Fund; International Council for Control of Iodine Deficiency Disorder. Report of a Joint WHO/UNICEF/ICCIDD Consultation on Indicators for Assessing Iodine Deficiency Disorders and 
their Control Programmes. Geneva, Switzerland: World Health Organization; 1992 22-29

18 Indicators for trackling progress in IDD elimination, In: IDD Newsletter; 1994 ; 10: 37-41

19 World Health Organization. A Guide for Programme Managers. Assessment of Iodine Deficiency Disorders and Monitoring Their Elimination, 2nd ed. Geneva, Switzerland: World Health Organization; 200124

20 Centers for Disease Control and Prevention. Epi Info version 3.5.1, 2008. www.cdc.gov/epiinfo/. Accessed August 15, 2008

21 World Health Organization, United Nations Children's Fund; International Council for Control of Iodine Deficiency Disorder Progress Towards the Elimination of IDD. Geneva, Switzerland: World Health Organization; 1999, 2001

22 World Health Organization. United Nations Children's Fund; International Council for Control of Iodine Deficiency Disorder. Indicators for accessing progress in IDD elimination. IDD Newslett 1994;10:37-41
23 Misra S, Kantharia SL, Damor JR. Prevalence of goitre in 6-12 years school-going children of Panchmahal district in Gujarat, India. Indian J Med Res 2007;126(5):475-479

24 Chandra AK, Singh LH, Tripathy S, Debnath A, Khanam J. Iodine nutritional status of children in North East India. Indian J Pediatr 2006;73(9):795-798

25 Kamath R, Bhat V, Rao R, Das A, Ks G, Kamath A. Prevalence of goiter in rural area of Belgaum district, Karnataka. Indian J Community Med 2009;34(1):48-51

26 Biswas AB, Chakraborty I, Das DK, Chakraborty A, Ray D, Mitra K. Elimination of iodine deficiency disorders-current status in Purba Medinipur district of West Bengal, India. Indian J Public Health 2008;52(3):130-135

27 International Council for Control of Iodine Deficiency Disorder; United Nations Children's Fund; World Health Organization. Assessment of Iodine Deficiency Disorders and Monitoring Their Elimination. A Guide for Programme Managers. 2nd ed. WHO/NHD/0 1.1. Geneva, Switzerland: World Health Organization; 2001 